\title{
Students' Writing Ability on English Descriptive Text at Grade VIII in SMPN 33 Padang
}

\author{
Ade Dwi Jayanti \\ Politeknik Raflesia Curup \\ adedwijayanti@yahoo.com
}

\begin{abstract}
There are 5 indicators in writing descriptive texts such as: identification, description, use of language, vocabulary and mechanics. Based on the problems found at the beginning of the research, the purpose of this research was to find the students ability in writing descriptive text on English subject in SMPN 33 Padang. The type of research is descriptive research. Participants of the research were VIII's grade students at SMPN 33 Padang. Data obtained through writing descriptive text tests. The data is analyzed by combining Heaton's theory of assessment in writing and research rubrics about writing. The results of the research concluded that students' ability in writing identification was Good to Average, students' ability in writing descriptive was Fair to Poor, students' ability in language use was Very Poor, students' ability in using vocabulary was Fair to poor, and students' ability in using mechanics was Fair to Poor. Then, the results of the research also showed that students had difficulty in identifying objects clearly, difficulties in developing related ideas, students' lack of understanding of simple present tense structures, limited vocabulary, and errors in mechanics.
\end{abstract}

Keywords: Writing Ability, English Descriptive text.

\section{INTRODUCTION}

Writing is one of English skills that must be learned by the students. To acquire it, the students should get sufficient writing practices. These practices are supposed to stimulate the students' skill in writing and expressing thoughts in a good passage. Without practicing, it is impossible to write well and effectively. Writing can be 
said as a language skill used to communicate indirectly, whether people can't face to face each others. Expressing thought in writing is not easy for most people, and it plays an important role in learning process because writers are able to explore their own knowledge and what they are thinking about to others.

Through writing activity, the students can develop their thinking knowledge, and their ability in English such as grammar and vocabulary. Raimes (1983: 4) says; there are some functions of writing: to communicate with a reader, to express ideas without pressure a face to face communication, to explore a subject, to record experience and to become familiar with the conventions of written English discourse (a text). So, it's very useful in our live because we can communicate, express ideas with a reader. If we have something, feelings, or ideas in our mind, we can use the writing to express all of them. Byrne (1984: 1) adds that "writing involves the encoding of message of some kind; that is, we translate or thoughts into language." The statement above is similar to Raimes' opinion that writing has function to send our minds into language to the readers.

The close relationship between writing and thinking makes writing a valuable part of any language course. Through writing we can express our ideas and thought in our attempt to make meanings. Ur (1991:163) states that "the purpose of writing, in principle, is the expression of ideas, that conveying of a message to the reader; so the ideas themselves should arguably be seen as the most important aspect of the writing." It means that not writing only, but we need to pay attention to several aspects of the writing, so the readers are able to getting point of ideas or messages. Clearly, that writing itself means the complex skill because there are several aspects to be considered like the content, the form, grammar, style and coherence. If someone have the ability to express their ideas into a sentence grammatically and effectively.

According to Kevin (2009: 1), there are ten main criteria of a good writing: a clear point, length, back up of point, time, logical, good grammar, English, and spelling, readers become engaged, rules are broken, influence and from their heart, not just created to profit or for gains. Based on the theory above, the criteria is also important things be thought by people in order to get a good writing. So, when the readers read it, they can get a good idea of how the writer feels about what they are writing about, even though no clear evidence is given in writing itself. Besides that, there is still opinion about the criteria of good writing shared by Fawcett, S. and Sandberg, A. (1990: 8): "criteria for judging good writing are: organization, unity, coherence, conciseness, clarity, grammar, punctuation, spelling and usage." If this is compared to Kevin's theory, the criteria of a good writing is not only clear point, 
good grammar, length, spelling, logic, etc, but also organization, coherence, conciseness, clarity, punctuation and usage.

Dealing to explanation above, writing descriptive text has to be learned by the students. According to Gerot and Wignell (1994: 208), "descriptive text is a text type we use when we want to tell how something looks, smells, feels, acts, tastes, sound etc". Basically, it provides details about characteristics of people, places, and things. The details are used to help the reader in creating a mental picture.

Moreover, Abisamra (2001: 1) has similar opinion about descriptive text. He adds that "descriptive is the text picturing the person, place and thing with clear detail to help the readers visualize an object which is described". So, by writing a descriptive text, the writers will create their sense of impression and get a clear picture of the object which is describe. Furthermore, description activity is used to describe an object and the readers become easily to be understood, so that they can imagine the object which is described clearly like the real one.

Gerot and Wignell (1994: 208) add that there are two generic structures of descriptive text; namely, identification and description. In identification, the learners will identify phenomenon or subject that is going to be described. While, description, the learners will describe specifically parts, qualities, and characteristics of an object that is being described. Furthermore, they also explain about the grammatical features (language features (simple present tense, action verb and adjective), vocabulary, and mechanics) of descriptive text. Related to idea above, there are some indicators of English descriptive text, namely; generic structure (identification and description), and grammatical features (language features (simple present tense, action verb, adjective), vocabulary and mechanics).

Based on KTSP (Kurikulum Tingkat Satuan Pendidikan) 2006 of Junior High School, kinds of texts are introduced to students from the first year until the third year at junior high school. One of them is descriptive text that had been learned by second year students of junior high school. But, the students usually faced difficulty in writing descriptive text because it must use present tense which is complicated for them and they have the little vocabulary in writing especially in writing a descriptive text. Related to this case, the writer interviewed some English teachers in SMPN 33 Padang. They said that the students don't understand in writing descriptive text because they have limited vocabularies and grammatical skills. It is supported by less knowledge about the elements of writing descriptive text. Thus, they aren't interested to write it. Furthermore, they added, "The students often 
ignored the punctuation and spelling, which made unmeaningful words. It was proved by the fact in their test result of writing descriptive text about their moms last semester that 2 students $(8,70 \%)$ were good to average, 7 students $(30,43 \%)$ were fair to poor and 14 students $(60,87 \%)$ were very poor." (Based on Heaton's scale)

The writer has three reasons why she is interested in doing this research about students' writing ability on English descriptive text. The first reason is that writing is a difficult activity for the eighth grade of SMPN 33 Padang. The second reason is that descriptive text must be written in present tense. Then, the last reason is that the eighth grade students usually have little vocabulary in writing text.

Based on the students' difficulty in writing descriptive text, the writer wants to do the research entitled "Students' Writing Ability on English Descriptive Text at Grade VIII in SMPN 33 Padang."

\section{THEORITICAL FRAMEWORK}

\section{Writing}

As we know, there are four common English skills that must be mastered by the students, they are: listening, reading, speaking and writing. Writing is also media of communication that can help us to have good socialization; we can express our idea, feeling, and our opinion through written language. Through writing activity, we can develop our thinking knowledge, and our ability in English such as grammar and vocabulary. Raimes (1983: 4) says;

Writing can impose grammatical structure, idioms, and vocabulary of the students. There are some functions of writing: to communicate with a reader, to express ideas without pressure a face to face communication, to explore a subject, to record experience and to become familiar with the conventions of written English discourse (a text). Based on the Raimes' opinion, writing is very useful in our live because we can communicate, express ideas with a reader. If we have something, feelings, or ideas in our mind, we can use the writing to express all of them.

In other opinion, Byrne (1984: 1) says that "writing involves the encoding of message of some kind; that is, we translate or thoughts into language." The statement above is similar to Raimes' opinion that writing has function to send our minds into language to the readers.

Oshima and Hogue (1991: 3) define that "writing is so important in academic life that some universities have on-line writing centers. These 
sites offer extra writing advice and information." It means that the students have to study and practice it deeply in their daily activities because it is very useful for their advanced, especially in education. Ur (1991:163) states that "the purpose of writing, in principle, is the expression of ideas, that conveying of a message to the reader; so the ideas themselves should arguably be seen as the most important aspect of the writing." It means that not writing only, but we need to pay attention to several aspects of the writing, so the readers are able to getting point of ideas or messages.

Nowadays, it is not only using speak-up to share our ideas or our messages, but also writing as one of media. It is a complex activity which involves many aspects and considerations. According to Nunan (2003: 88), writing is a complex process. It involves a physical and mental act. Physical is related to send the word or ideas to specific medium such as letters, hand writing, or others. Mental work is the process of the expressing the ideas, and thinking in delivering the message into written language. It means that the students can share all their minds, opinions or everything through writing. For example, when students have criticism to their school's rules, they can apply it in writing.

Writing can be said as a language skill used to communicate indirectly, whether people can't face to face each others. Expressing thought in writing is not easy for most people, and it plays an important role in learning process because writers are able to explore their own knowledge and what they are thinking about to others. The close relationship between writing and thinking makes writing a valuable part of any language course. Through writing we can express our ideas and thought in our attempt to make meanings. The writing itself means the complex skill because there are several aspects to be considered like the content, the form, grammar, style and coherence. It means the writer should use good grammar and adequate vocabulary in making good writing. If someone has the ability to express their ideas into a sentence grammatically and effectively, the writing can be enjoyable for them. Of course, it is not enjoy for them only, but also for the readers because they can comprehend it easily.

Sometimes people put writing activity as their hobby. Through writing they can create something in written form. For example, they can make letter, poetry, story, novel, and even they can give advices or critics to someone through writing. In short, we write to learn, usually for private purposes. And then we write to communicate, usually for public purposes. 
Related to definitions of writing above, most of people are interested to a good piece of writing. Of course it makes them become easy to get ideas while reading it. Here, Kevin (2009: 1) has ten main criteria of a good writing. He says, There are many criteria of a good writing. A good writing has some criteria; a clear point, length, there is information to back up your point, time, logical, good grammar, English, and spelling, readers become engaged, rules are broken, influence and from their heart, not just created to profit or for gains.

Based on the criteria above, it is also important things be thought by people in order to get a good writing. So, when the readers read it, they can get main point of how the writer feels about what they are writing about, even though no clear evidence is given in writing itself. Besides that, there is still opinion about the criteria of good writing shared by Fawcett, S. and Sandberg, A. (1990: 8): "criteria for judging good writing are: organization, unity, coherence, conciseness, clarity, grammar, punctuation, spelling and usage." Based on the theory above, if it's compared to Kevin's theory, the criteria of a good writing is not only clear point, good grammar, length, spelling, logic, etc, but also organization, coherence, conciseness, clarity, punctuation and usage.

Related to the criteria above, there are some steps in writing activity must be followed by the writers. Here, Brereton (1982: 1) states " six separate steps most good writers follow: discovering a topic, planning an approach, writing a rough draft, revising, writing a final draft, and proofreading."

The steps above are similar to Oshima and Hogue's opinion (1991: 3 ) that "there are four main stages in the writing process: prewriting, planning (outlining), and writing and revising drafts, and writing the final copy to hand in." They add a simple conclusion about some steps in the writing process, such:

a. Step 1 (Prewriting): brainstorming.

b. Step 2 (Planning): developing an outline.

c. Step 3 (Writing): writing a rough draft.

d. Step 4 (Revising): editing the rough draft for content and organization.

e. Step 5 (Rewriting): writing a second draft, and proofreading it for grammar and mechanics.

f. Step 6: writing a final copy to hand in.

So, before writing, it is important to make concept of the text. So, when a writer will be doing the writing process, she/ he will not be 
overlap from the topic. Thus, those steps of writing should be done by students in order to get a good writing.

Based on the experts' ideas above, a simple conclusion can be drawn that we can write effectively if we are willing to learn or follow those criteria and practice them. Besides that, it can make the readers understanding the point and can get the aims of the writing.

\section{a. Descriptive Text}

A text is the original words and form of a written or printed work." In other words, it consists of spoken or written words that have the purpose of conveying message". It means that by putting the words together to communicate a meaning or to send a message, so a piece of text is created.

In addition, according to Hyland (2005), Texts are autonomous objects which can be analyzed and described independently of particular context, researchers or readers. Texts have their structures. They are orderly arrangement of words, clauses, and sentences by following the principles which guide the correct arrangement of elements. Researchers can encode full semantic representation of their intended meaning.

It means that text consists of words, clauses and sentences which arranged to be one unity. Thus, a simple conclusion can be drawn that texts are group of words, clauses, sentences or organize patterns of spoken or written language. The texts are not only having purpose, but also meaning.

One factor that affects to differences in text is the purpose for which the text being used. When constructing a piece of text, the writer or the researcher makes choices about words used and how these words will be put together. The choices of words will depend on the purpose and context of the text. Texts can be said as structures in different ways to achieve their purpose. For example, the purpose of descriptive text is to describe a something, place or people.

Descriptive text is a text that is always in around us when we want to describe something or someone. It is learnt by Junior High School (SMP) in the first and second years. In general, descriptive means describe about particular person, place or thing details. Descriptive text should concentrate on action (verbs), rather than sensation (adverbs and adjectives). Descriptive text has generic structures and language features. Writer should assume the role of readers whose idea of the described events, in entirety, constructed by text content. Abisamra (2001: 1) adds that "descriptive is the text picturing the person, place 
and thing with clear detail to help the readers visualize an object which is described". So, by writing a descriptive text, the writers will create their sense of impression and get a clear picture of the object which is described. Furthermore, description activity is used to describe an object and the readers become easily to be understood, so that they can imagine the object which is described clearly like the real one.

According to Gerot and Wignell (1994: 208), "descriptive text is a text type we use when we want to tell how something looks, smells, feels, acts, tastes, sound etc". It means that when we want to describe how something looks, smells, feels, acts, tastes, sound to someone by a text, we can create descriptive text. Basically, it provides detail information about characteristics of people, places, and things. The detail information is used to help the reader in creating a mental picture. In short, the descriptive text is emphasized about text to tell something details. They add that there are two generic structures of descriptive text; namely, identification and description. In identification, the learners will identify phenomenon or subject that is going to be described. While, description, the learners will describe specifically parts, qualities, and characteristics of an object that is being described. Furthermore, they also explain about the grammatical features (language features (simple present tense, action verb and adjective), vocabulary, and mechanics) of descriptive text.

Related to ideas above, there are some indicators of English descriptive text. First, generic structure (identification is to identify phenomenon be described, and description is to describe parts, qualities, and characteristics of subject). And secondly, the grammatical features (focus on language features (simple present tense, action verb, adjective), vocabulary and mechanics).

\section{b. Generic Structures of English Descriptive Text}

In addition, Hardy and Klarwein (1999: 1) have opinion about generic structures of descriptive text: The generic structure of descriptive text contains definition and description. Description consist of description of purpose, description of features and their use, description of physical features, description of people, description of properties and interesting facts, and description of evidence today.

Gerot and Wignell (1994: 208) and Yusak (2004: 49) add their opinion about generic structures of descriptive text. They say that there are two generic structures of descriptive text as follows:

\section{a. Identification}

Identification is necessary in order to avoid having general statement. It means that a writer needs to identify which particular 
thing. In this case, it identifies a phenomenon or a subject that is going to be described. The subject can be a person, thing or place. Masruri (2010: 1) adds that identification is a part of paragraph which introduces or identifies the character. If a student writes an identification part clearly, he/she will develop the ideas easily in description part. It means that, the sentence or paragraph can guide the student to organize and develop ideas to be good writing.

\section{b. Description}

It describes specifically parts, qualities, and characteristics of a phenomenon or a subject details that is being described. Masruri (2010: 1) adds that description is a part of paragraph which describes the character. So, the writer describes all information related to topic.

Then, the ideas should be good organized. In this case, each of idea has relationship and organized. So, the reader can comprehend well what the English descriptive text is about. It means that the reader will get a clear picture of the phenomenon or subject which is described in English descriptive text if the writer expresses the message clearly although the readers are not faced with the writer directly.

\section{c. The Grammatical Features of English Descriptive Text}

The grammatical features of descriptive text focus on Language features (simple present tense, action verb and adjective), vocabulary and mechanics.

\section{a. Language Features (simple present tense, action verb, and adjective)}

According to Peronity (2011: 1), "the language features of descriptive text are use of simple present tense because it tells the object description, use of the adjective to clarify the noun", for example: a beautiful girl, a handsome man, the famous place in Bengkulu, and use of action verb to show an activity (activity can be seen) for example: use, write, bring, etc. Simple present tense is the most popular tense in using. This is due to the factual nature of a descriptive text. In this case, it is one of tenses which is students should master in writing English descriptive text. If the students master it, they are easier to express ideas into good writing. Azar (2005) states; Simple present tense has patterns, they are; 1)verbal sentence, and 2)nominal sentence. In verbal sentence, the formula as follows;

$$
\begin{gathered}
(+) S+V 1(s / e s)+O / C \\
(-) S+d o / d o e s+n o t+V 1+O / C
\end{gathered}
$$


i.e. My mother cooks the cake in the kitchen.

In nominal sentence, the formula as follows;

(+) $S+$ Tobe (is, am, are) + Adjective /Adverb

(-) $S+$ Tobe (is, am, are) + not + Adjective/Adverb

i.e. Tom cruise is handsome man.

Furthermore, using adjective in writing English descriptive text is up the writer to create excitement, interest, and beauty with their words. It means that adjectives are words that modify a noun or pronoun. It is to give more information so that the writer's meaning is clear to the reader. According to Parrot (2004: 18), adjectives are class of words often called as describing words because they provide information about the qualities of something described in nouns, noun phrases or clauses. The examples are below:

Noun : an old house

Noun phrase : an interesting adventure for everyone

Clause $\quad$ : it will be unforgettable moment that we have in our lives

The aspect of writing deals with acceptable words, phrases, clauses, or sentences in following grammar rules of the text.

\section{b. Vocabulary}

Vocabulary is important in writing English descriptive text. It can be said as necessity to be known by students in Junior high school. A writer can make readers explore more deeply in what is telling about. In fact, it is always become a big problem in learning English. Students are still difficult in writing text because they have less of vocabulary. So, they cannot convey their ideas related to topic clearly as they would have to.

Vocabulary is a core component in studying a language. It is supported by Zhihong (2000) states that "Words are the basic unit of language form. Without a sufficient vocabulary, one cannot communicate effectively or express ideas. Having a limited vocabulary is a barrier that prevents students from learning a foreign language. If learners do not know how to expand their vocabulary, they gradually lose interest in learning" 
Based on the theory above, it can be concluded that vocabulary has important role in communication. We cannot send our ideas to readers without enough vocabularies. Besides that, using a word in writing text is not only implies a definition, but also implies how that word fits into the context. It means that the writer has to smart in choosing the appropriate word so it relates to the context. If the word is not appropriate into the context, so the readers have difficulties in comprehending the text. Related to writing descriptive text, students have difficulties in choosing appropriate words to express their ideas. As a result, the students cannot finish their descriptive writing. So, this case means the students have to use appropriate vocabularies and accurate words fix to the context in their English descriptive text. Students will advance their ability in writing English descriptive text by using appropriate words.

\section{c. Mechanics}

Heaton (1988: 148) states "the mechanic concerns about the writers' ability to use correctly those conventions peculiar to the written language - such as punctuation and spelling." Mechanic of writing also refers to the use of capitalization. According to Nordquist (2011: 1), mechanics consist of punctuation and spelling. The punctuation means a set of marks used to regulate texts and clarify their meanings, principally by separating or linking words, phrases, and clauses. Furthermore, Longman (1998: 389) adds that "punctuation is one art or practice of inserting of standardized marks or sign in written matter to clarify the meaning and separate structural unit. It has two functions; they are to clarify the meaning and to separate structural unit." Then, Oshima and Hogue (1991: 245) add "using correct punctuation is important because it conveys meaning just as words do." While the spelling means the word looks like. If the writer wrote wrong spelling, so it will create un-meaningful words.

It can be concluded that punctuation and spelling is important in writing to help readers to understand the writer's ideas. In learning English, both of them are accurately presented and learned. By using punctuation, bring clarity in writing and making it comprehensible. While, spelling means the word looks like, if spelling incorrect so the meaning of word can be different.

\section{d. Testing Writing}

O'Malley and Pierce (1996: 139) states that in examining the nature of writing, we have looked at the writer and the type of writer's knowledge which is bring to the writing task. We have to indicate the purpose and genre of writing to determine what and how students' 
writing. The task may consist of the questions or statement that the students will address in their writing and conditions under which they will write. They should be allocated to the time and resources. The students don't be asked to write a task if it is not suitable with their readiness.

According to O'malley and Pierce (1996: 140), testing writing is to know the students' ability in using language and the students' ideas through written medium. The purpose of teaching and learning writing is to enable the students to use the language skills in social life. In teaching and learning writing, the students are hoped to able to express the idea into written language.

Heaton (1988: 7) says that by testing writing, it will provide the students with an opportunity to show their ability to perform certain tasks in the language. So, the students can learn from their weaknesses. In order to know the students' achievement in writing, testing writing ability is the best choice. Here, the students are asked to write. The students can write about the personal descriptive. The teacher can ask the students to write their experience and scores the task based on the criteria of scoring.

Heaton (1988: 146) has opinion related to scoring writing. He says that there are some components of scoring writing. They are content (subject), organization (ideas), language uses (simple present tense/ construction), vocabulary (choice of words), and mechanics (spelling and punctuations). First, content is about knowledge of subject. Second, organization expresses facts, ideas, feelings and attitudes clearly in writing. Third, language use is often concerned the formal patterns of language (described in prescriptive grammars and lexicons). It means that it is concerned with students' knowledge of forms of language. Fourth, vocabulary is concerned with word meanings, words formation and collocation. And finally, mechanics refers to punctuation and spelling.

Furthermore, the writer gave an example of English descriptive text which had been quoted from Genres of text book created by Hartono (2011: 25) in order to make this research clearly. After that, she explained five indicators (identification, description, language feature, vocabulary and mechanics) of English descriptive text.

\section{Review of the Related Findings}

Before conducting the research, the writer found some researchers who have done the research about students' writing especially about writing descriptive text in right order. Firstly, it was conducted by 
Trilisnawati (2012). She analyzed about error analysis on descriptive text, a case study at the eighth grade of SMP Islamiyah Sawangan. The writer found some errors made by the students in writing. She analyzed the common errors in the article, personal pronouns, subject-verb agreement, capitalization, spelling, and non-count nouns. The writer analyzed 20 research samples and found most students made errors in their writing. The writer discovers that the error types in the use of article, personal pronouns, subject-verb agreement, capitalization, spelling, and non-count nouns, committed by eighth grade students of SMP Islamiyah Sawangan. The students still confuse with the forms of writing, especially in using the personal pronouns.

Secondly, it was conducted by Natria (2007). The design of her research was descriptive in nature. She analyzed about eighth year students' errors of SMP N 2 Brebes in using simple present tense in descriptive texts. She used Cluster proportional random sampling technique to collect the data. In her research, she found out the dominant errors on simple present tense in writing descriptive texts and the possible causes of those errors. She used a writing test as an instrument. In her result, there were 10 types of errors. They were omission of be, wrong form of be, double be, wrong use of singular and plural form, addition of be (before and after verb), omission of suffix s/-es, wrong use of verb, wrong form of modal auxiliary, omission of verb, and wrong form of negative sentence.

Thirdly, it was conducted by Shokrpour and Fallahzadeh (2007). The research was about EFL Writing Problems in Shiraz University of Medical Science, trying to point out the major difficulties with which Iranian students face when writing their report. The specific objective of this research was to determine whether language skills or writing skill of medical students are the major problem areas to medical students. The data analysis indicates that Iranian EFL medical students have problem both in language and writing skills, but with higher percentages of problem in writing skill.

The above researchers were related to this research. Here, the writer studied students' writing ability of English descriptive text of grade VIII in SMPN 33 Padang, in descriptive qualitative research by using writing test. She chose one class of its level as a participant. The students were asked to write a descriptive text. Here, she analyzed about students' ability in writing English descriptive text. She analyzed about generic structure (identification and description), language feature (using simple present tense, adjective, action verb), vocabulary and mechanics in writing text. In collecting the data, she used the 
Heaton's scoring rubric writing and Gerot \& Wignells' theory about indicator of English descriptive text. She combined both of them. Besides that, she also categorized the students' ability. Then, she counted its frequency and percentage.

\section{RESEARCH METHODHOLOGY}

The research designed as a descriptive quantitative research. The purpose of the research is to gain information about phenomena in order to describe existed condition in the field. So, the students' writing ability on English descriptive text is analyzed by using quantitative method. It was conducted in SMPN 33 Padang. The participant of this research was grade VIII students of SMPN 33 Padang. There are about 23 students as the subject of the research, of which 13 students are female and 10 students are male.

This research used writing test as the instrumentation or the way to collect the data of students' writing ability of English descriptive text. Heaton (1988: 7) states that testing writing provides the students with an opportunity to show their ability to perform certain tasks in the language. In order to know the students' achievement in writing, testing writing ability is the best choice.

In this research, the writer (as scorer I) was helped by the English teacher of second year of SMPN 33 Padang (as scorer II) to give the score on students' writing in English descriptive text. Before giving the test, the writer tried out the test to participants. In this case the writer tried out the instruction of the test to make sure whether the students understand or not what they will do with the test and whether or not the participants can write a English descriptive text in the allocated time.

The test was developed from some indicators of English descriptive text, such as identification, description, language features (simple present tense, action verbs, and adjective), vocabulary, and mechanics (punctuation and spellings). The writing test was done in three meetings. There are 60 minutes for each meeting. The writer gave three topics for each test, namely; my mom, my bag and my school.

The data were analyzed quantitatively method. The writer found the students' score by using combined scoring rubric writing by Heaton (1988: 146) and indicators of English descriptive text. Furthermore, the writer calculated the students' score by combining scores from both scorers. 


\section{FINDINGS AND DISCUSSIONS}

The figure 1 presented students' writing ability of five indicators in English descriptive text. The following figure also presented the number of students for each category.

Table 1: The Categorization of students' ability in Writing English Descriptive Text

\begin{tabular}{|c|c|c|c|}
\hline $\begin{array}{c}\text { Interval } \\
\text { scores }\end{array}$ & $\begin{array}{c}\text { Categorization of } \\
\text { Students' ability }\end{array}$ & $\begin{array}{c}\text { Freq. of } \\
\text { Stud.(f) }\end{array}$ & $\begin{array}{c}\text { Percent. } \\
(\%)\end{array}$ \\
\hline $3.51-4$ & Excl. to very good & 0 & $0 \%$ \\
$2.51-$ & Good to average & 1 & $4.35 \%$ \\
3.50 & Fair to poor & 21 & $91.3 \%$ \\
$1.51-$ & Very poor & 1 & $4.35 \%$ \\
$1-1.50$ & & $\sum \mathrm{n}: 23$ & $\sum: 100 \%$ \\
\hline & & & \\
\end{tabular}

From the figure 1, it could be seen that 21 students' ability was fair to poor. While, none of student's ability was excellent to very good, 1 student's ability was good to average, and 1 student's ability was very poor. It means that $91 \%$ of students at grade VIII.5 are enough difficult in writing English descriptive text.

After that, the writer analyzed each indicators of writing English descriptive text such as identification, description, language features, vocabulary and mechanics. Then, she analyzed the problem for each indicator faced by students in writing English descriptive text.

\section{Students' Ability in Writing Identification}

Identification is one of the indicators of descriptive text. The students' writing ability was described as follow:

Table 2.

The Categorization of Students' Ability in Writing Identification

\begin{tabular}{|c|c|c|c|}
\hline $\begin{array}{c}\text { Interval } \\
\text { Scores }\end{array}$ & $\begin{array}{c}\text { Categorization of } \\
\text { Students' ability }\end{array}$ & $\begin{array}{c}\text { Freq. of } \\
\text { Stud. }(f)\end{array}$ & $\begin{array}{c}\text { Percent. } \\
(\%)\end{array}$ \\
\hline
\end{tabular}




\begin{tabular}{|c|c|c|c|}
\hline $3.51-4$ & Excl. to very good & 0 & $0 \%$ \\
$2.51-3.50$ & Good to average & 14 & $60.9 \%$ \\
$1.51-2.50$ & Fair to poor & 9 & $39.1 \%$ \\
$1-1.50$ & Very poor & 0 & $0 \%$ \\
\hline & & $\sum \mathrm{n}: 23$ & $\sum: 100 \%$ \\
\hline
\end{tabular}

From the figure 2 above, it showed that 14 students were good to average, while 9 students were fair to poor. It can be said that most of students are able to write identification. According to Gerot and Wignell (1994: 208), "in identification, the learners identify phenomenon or subject that is going to be described." Related to this case, there is only simple problem faced by few students in this indicator. They identify the object (person, thing or place) unclearly.

\section{Students' Ability in Writing Description}

Next, description is the second indicator of descriptive text. The students' writing ability was described as follow:

Table 3.

The Categorization of Students' Ability in Writing Description

\begin{tabular}{|c|c|c|c|}
\hline $\begin{array}{c}\text { Interval } \\
\text { Scores }\end{array}$ & $\begin{array}{c}\text { Categorization of } \\
\text { Students' ability }\end{array}$ & Freq. of Stud. $(f)$ & $\begin{array}{c}\text { Percent. } \\
(\%)\end{array}$ \\
\hline $3.51-4$ & Excl. to very good & 0 & $0 \%$ \\
$2.51-3.50$ & Good to average & 0 & $0 \%$ \\
$1.51-2.50$ & Fair to poor & 20 & $87 \%$ \\
$1-1.50$ & Very poor & 3 & $13 \%$ \\
\hline & & $\sum \mathrm{n}: 23$ & $\sum: 100 \%$ \\
\hline
\end{tabular}

From the figure 3, it showed that 20 students were fair to poor, while 3 students were very poor. It can be said that many students have problems to describe an object of the text detail. They are unable to develop ideas or information related to object (person, thing or place) in order to make descriptive text clearly. According to Abisamra (2001: 1 ), "descriptive text is the text picturing the person, place, and thing detail to help the readers visualize an object which is described." So, it effects the readers be difficult to understand and comprehend deeply about the object. It is also supported by Grellet's theory (1990:3). He 
states that "understanding a written text means extracting and requiring information from it as efficiently as possible." Related to this case, the students have to develop ideas and describe all information which related to an object (person, thing or place) in order to help the reader get a clear picture.

\section{Students' Ability in Using Language features}

Moreover, language features is the third indicator of descriptive text. The language features concern to use of simple present tense, use of action verbs, and use of adjective. The students' writing ability was described as follow:

Table 4.

The Categorization of Students' Ability in Using Language Features

\begin{tabular}{|c|c|c|c|}
\hline $\begin{array}{c}\text { Interval } \\
\text { scores }\end{array}$ & $\begin{array}{c}\text { Categorization of } \\
\text { Students' ability }\end{array}$ & $\begin{array}{c}\text { Freq. of } \\
\text { Stud. }(f)\end{array}$ & $\begin{array}{c}\text { Percent. } \\
(\%)\end{array}$ \\
\hline $3.51-4$ & Excl. to very good & 0 & $0 \%$ \\
$2.51-3.50$ & Good to average & 1 & $4.3 \%$ \\
$1.51-2.50$ & Fair to poor & 12 & $52.2 \%$ \\
$1-1.50$ & Very poor & 10 & $43.5 \%$ \\
\hline & & $\sum \mathrm{n}: 23$ & $\sum: 100 \%$ \\
\hline
\end{tabular}

From the figure 4, it showed that only one student was good to average. While, 12 students were fair to poor and 10 students were very poor in using language features (simple present tense, action verb, and adjective). In general, it might be caused by a factor which the students do not know the basic structure of simple present tense itself. So, it makes error structure of sentences which is written by students. In specifically, most of them had omission of be, wrong use of singular and plural be, omission of suffix -s/-es and wrong use of verb. Sometimes the students used plural verb for singular subject. Oshima and Hogue (1988: 13) state that "subjects and verbs of sentence must be agreed in number." Unfortunately, many students do not know how to differentiate between a singular subject and a plural subject in writing a sentence. Related to this problem, the students often use ordinary verb "have" to third singular subject. 
Besides that, many students also often make mistakes in using V1 and V1+s/es. They don't use V1s+es for third singular person "she, he". Jack (2003: 31) adds that "in simple present tense, verb is changed to be Verb +s/es for third singular person." It means that if subject of sentence is third singular person/impersonal "she, he, it", V1 is added $+\mathrm{s} / \mathrm{es}$. While, if subject is first singular person "I", second singular person "you", first plural person "we", second plural person "you", and third plural person "they", it uses V1 only.

Furthermore, many students are confused to put adjective in writing. They often put adjective after noun/ object. According to Jack (2003:198), "an adjective is usually followed by "to be"." So, the students should put adjective after to be (before noun) to explain noun of sentence. Those data indicated that using language features in writing English descriptive text is difficult for students. Thus, they need to learn it deeply in learning of English writing.

\section{Students' Ability in Using Vocabulary}

Furthermore, vocabulary is the fourth indicator of descriptive text. The students' writing ability was described as follow:

Table 5.

The Categorization of Students' Ability in Using Vocabulary

\begin{tabular}{|c|c|c|c|}
\hline $\begin{array}{c}\text { Interval } \\
\text { scores }\end{array}$ & $\begin{array}{c}\text { Categorization of } \\
\text { Students' ability }\end{array}$ & $\begin{array}{c}\text { Freq. of } \\
\text { Stud.(f) }\end{array}$ & $\begin{array}{c}\text { Percent. } \\
(\%)\end{array}$ \\
\hline $3.51-4$ & Excl. to very good & 0 & $0 \%$ \\
$2.51-3.50$ & Good to average & 1 & $4 \%$ \\
$1.51-2.50$ & Fair to poor & 20 & $87 \%$ \\
$1-1.50$ & Very poor & 2 & $9 \%$ \\
\hline & & $\sum \mathrm{n}: 23$ & $\sum: 100 \%$ \\
\hline
\end{tabular}

From the figure 5, it showed that only 1 student was good to average. While, 20 students were fair to poor and 2 students were very poor in using vocabulary. This data indicates that most of students have poor vocabulary in English. Here, many students use general vocabularies in writing English descriptive text. According to Brown (2004: 301), vocabulary is important to get comprehension of the text. Related to this theory, many students do not have many vocabularies. Even they use some Indonesian in writing. Therefore, the text which is written can be difficult to be comprehended. 
Sometimes the students use the vocabularies which not related to the topic. Stahl (2005) states that vocabulary is the knowledge of words and word meanings and also puts vocabulary knowledge as the knowledge of a word not only implies a definition, but also implies how that word fits into the context. In reality, many students use vocabulary which were unsuitable contextually. As a result, it makes the reader do not get information of the text. So, it is important for students to enrich their vocabulary in English in order to develop their ideas to be good writing, even, make reader easily to understand and comprehend the text.

\section{Students' Ability in Using Mechanics}

Last indicator of descriptive text is mechanics. Mechanics concern to punctuation and spellings. The students' writing ability was described as follow:

Table 6.

The Categorization of Students' Ability in Using Mechanics

\begin{tabular}{|c|c|c|c|}
\hline $\begin{array}{c}\text { Interval } \\
\text { scores }\end{array}$ & $\begin{array}{c}\text { Categorization of } \\
\text { Students' ability }\end{array}$ & $\begin{array}{c}\text { Freq. of } \\
\text { Stud. }(f)\end{array}$ & $\begin{array}{c}\text { Percent. } \\
(\%)\end{array}$ \\
\hline $3.51-4$ & Excl. to very good & 0 & $0 \%$ \\
$2.51-3.50$ & Good to average & 1 & $4 \%$ \\
$1.51-2.50$ & Fair to poor & 19 & $83 \%$ \\
$1-1.50$ & Very poor & 3 & $13 \%$ \\
\hline & & $\sum \mathrm{n}: 23$ & $\sum: 100 \%$ \\
\hline
\end{tabular}

From the figure 6 , it showed that only 1 student was good to average. While, 19 students were fair to poor and 3 students were very poor. It means that many students had some mistakes / errors in using mechanics to write English descriptive text. It might be caused by the students do not comprehend about punctuation and spelling.

Firstly, punctuation, many students don't use period (.) at the end of sentence. It is seem as if the sentence connected to the next sentence. Oshima and Hogue (1988:10) state that "there are three punctuation marks that can be used at the end of a sentence: the period (statement), the question mark (question), and the exclamation mark (to show strong feeling)." 
Sometimes some students put commas (,) in uncorrected position, such; putting comma at the end of sentence. According to Boardman and Frydenberg (2001:39), "when a word, a phrase, or a dependent clause comes before an independent clause, we use a comma after it and before the independent clause." So, it makes the text be ambiguously. If students write comma at the end of sentence, it usually means the sentence has been finished yet.

Besides that, some students also write a run-on sentence which is caused by have no punctuation. As a result, the readers are difficult to comprehend the text when check the students' writing. Thus, by using correct punctuation, the students can write sentence clear. Then, the reader can comprehend the meaning of its sentence. It is supported by Oshima and Hogue (1988:10) who state that "punctuation is necessary to make sentence meaning clear."

Secondly, spelling, many students did miss-spelling in writing words. The data indicated that the students cannot differentiate written of word to its pronunciation. Zaim (2005: 124) states that, "each word has meaning."If they do miss-spell in writing words, it will probably have no meaning. It reflects to their writing, of course. It means that they cannot inform the text about to reader. According to Leo Sutanto, e.l. (2007), if the writer writes a clear word, the readers can expect a clear picture of what the writer intends to tell them. Related to this problem, the reader has difficulty to get information related to subject of English descriptive text written by students. Even, the reader was confused to read the text.

\section{CONCLUSIONS AND SUGGESTIONS}

\section{Conclusion}

Based on the research findings, there are some conclusions which can be derived from the analysis:

In general, the students' writing ability of SMPN 33 Padang in writing English descriptive text is fair to poor. In specifically, it is found that the students' ability in writing identification (14 students: Good to average, and 9 students: Fair to poor), in writing description (20 students: Fair to poor, and 3 students: Very poor), in using language features (1 student: Good to average, 12 students: Fair to poor, and 10 students: Very poor), in using vocabulary (1 student: Good to average, 20 students: Fair to poor, and 2 students: Very poor), and in using mechanics ( 1 student: Good to average, 19 students: Fair to poor, and 3 students: Very poor) of English descriptive text. Meanwhile, the 
students have some problems in writing English descriptive text. They are:

a. Identification: Few students don't identify the object clearly in identification.

b. Description: Some students do not describe parts, qualities and characteristics of object in description. It was caused the students cannot develop their ideas or information related to object in order to make descriptive text clearly.

c. Language Features: In general, most of students do not know the basic structure of simple present tense itself. So, it affects error structure of sentences which is written by students. In specifically, most of them have omission of be, wrong use of singular and plural be, omission of suffix - s/-es and wrong use of verb. Furthermore, the students often use ordinary verb "have" to third singular subject because they do not know how to differentiate between singular and plural subjects in writing a sentence. After that, many students also often make mistakes in using V1 and V1+s/es. Finally, they often put adjective after noun/ object in writing sentence.

d. Vocabulary: Many students have poor vocabulary in English. Furthermore, many students use vocabulary which are unsuitable contextually. So, they need to enrich their vocabulary.

e. Mechanics: In punctuation, many students don't use period (.) at the end of sentence. Next, some students put commas (,) in uncorrected position, such; putting comma at the end of sentence. Furthermore, some students also write a run-on sentence which is caused by have no punctuation. The students have to pay attention to punctuation because it is necessary to make meaning clearly.

\section{Suggestion}

Based on the conclusions of the research, the writer would like to propose some suggestions as follows: (1) The English teachers are suggested to explain the generic structure and grammatical features of descriptive text more deeply and clearly in order to get good results for the students. (2) The English teachers are suggested to give more practices to the students in writing especially when they are writing English descriptive text by using interesting strategy related to the students' ability in developing their ideas. (3) The English teachers are suggested to stimulate the students to build ideas related to the topic. So, the students will be able to develop those ideas to be good writing. (4) The English teachers are suggested to be more active in teaching- 
learning process. Because of the English teacher has important role in learning successful.

\section{REFERENCES}

Abdullah, A. T. H. (2013). Error Analysis on the Use of Simple Tense and Simple Past Tense in Writing Essay among TESL College Students. International Journal of Education Research. Vol. 1 No 12. http://www.ijern.com/journal.December-2013/29.pdf. Retrieved, May 10th, 2019.

Abisamra, Nada. 2001. Teaching Writing Approach \& Activities. (Retrieved on January 2013). http://www.jstor.org/stable/40014588. Alawi, F.F. (2011). Improving Students' Ability in Writing Descriptive Text Using Clustering Technique. Journal of English Language Teaching. Vol 2. No.2, 2011

Alawi, F.F. (2011). Improving Students' Ability in Writing Descriptive Text Using Clustering Technique. Journal of English Language Teaching. Vol 2. No.2, 2011

Boardman. C. A. and Frydenberg, J. (2001). Writing to Communicate: Paragraphs and Essays. Second Edition. New York: Pearson Education.

Brown, H. D. 2004. Strategies for Success: A Practical Guide to Learning English. New York: Person Longman.

2010, language Assessment: Principles and Classroom Practices. Second Edition. New York: Person Longman.

Byrne. 1984. Teaching Writing Skill. London: Four Strong Printing Company.

Departemen Pendidikan Nasional. 2006. Kurikulum 2004. Standar Kompetensi Mata Pelajaran Bahasa Inggris. SMP \& MTS. Litbang.kemdikbud.go.id/content/buku standar isi SMP(1).pdf

Exdriko, Y. Tavriyanti, L. and Refnita, Lely. (2014) The Teaching of Writing a Descriptive Text Using Clustering Technique for Bung Hatta University Students. Journal=JFKIP Vol 3. No. 5, 2014 Retrieved from http://ejurnal.bunghatta.ac.id

Fawcett, S. and Sandberg, A. 1990. Business English: Skills for success. http://www.wilmu.edu/learningresorces/documents/criteriafori udgingwriting.pdf. 
Fitri, I., Eripuddin. and Rahayu,P. (2017). An Analysis of the Students' Skill in Writing Descriptive Text at The Eighth Grade of SMPN7 Tambusai Utara. E-Journal Mahasiswa Prodi Bahasa Inggris. Vol 3: No. 1, 2017. Retrieved from http://e-journal.upp.ac.id

Gay, L. R. and Airasian. 2000. Educational Research; Competencies for Analysis Application. (6 $6^{\text {th }}$ Edition). New Jersey: Prentice-Hall inc.

Gerot, L. and Wignell, P. 1994. Making Sense of Functional Grammar. Sydney: Antipodeon educational Enterprises (AEE) Publishing.

Grellet, F. 1990. Developing Reading Skill. New York: Cambridge University Press.

Heaton, J. B. 1988. Writing English Language Tests. London: Longman Group.

Hongqin, Z. (2014). Academic Writing Instruction for EFL Undergraduation: An Intelextuality Approach. International Journal of English and Education. ISSN 2278-4012. Vol 4. April 2014.

Husna, L. (2018). An Analysis of Students' writing Skill in Descriptive text at Grade XI Ipa 1 of Man 2 Padang. Jurnal Ilmiah Pendidikan Scholastic, 1 (1), 16-28. Retrieved from http://e-journal.sastraunes.com/index.php/JIPS/article/view/281

Jack, S. H. 2003. The Easiest Way of Comprehending English Grammar. Second Edition. Jakarta: Batavia Press.

Kevin. 2009. "Criteria of a good writing". (Retrieved on January 2012) http://blogtipz.com/2009/01/07/characteristics-good-writing/.

Leo, S.,Groth, C., Yugianingrum., Lilyana,S., Kendra,I.L.,and Lukman, E.A. 2007. English for Academic Purpose: Essay Writing. Ed. 1. Yogyakarta: ANDI.

Marom, S.N. (2016) Improving the Students' Skill inWriting Descriptive Text Using the Power of Two Strategy. Internatioanl Conference on Education. Vol. 1:No.1 2016. Retrieved from http://jurnal.unmuhjembe.ac.id

Myles, J. (2002). Second Language Writing and Research: The Writing Process and Error Analysis in Students Texts." Teaching English as a Second or Foreign Language. Vol. 6, No. 2. AI. Retrieved on May $10^{\text {th }} .2019$. 
Oshima, A. and Hogue,A. 1988. Introduction to Academic Writing. New York: Addison- Wesley Publishing Company, Inc.

1991. Writing Academic English: A Writing and Sentence Structure Handbook. Second edition. New York: Addison- Wesley Publishing Company, Inc.

Raimes, A. 1983. Technique in Teaching Writing. London: Oxford University Press.

Rass, H. (2001). Difficulties in Teaching and Learning Grammar in an EFL Context. International Journal of Instrcution. July 2001. Vol 4. No. 2 P-ISSN: 1694-609X.

Sa'diyah, H. (2010). Improving Students' Ability in writing Descriotive Text Through A Picture Series Aided Learning Strategy. The English Teacher Vol. XL: 164-182. Retrieved from: http://www.melta.org.my/ET/2011 182 Halimatus.pdf

Stahl, S. A. 2005. Four Problems with Teaching Word Meaning and what to do to make Vocabulary an integral part of instruction, Bringing Research to Practice. New Jersey: Prentice Hall Regent.

Ur, Penny. 1991. A Course in Language Teaching. English Teaching Forum. Vol.XXV No: 56. Cambridge: Cambridge University Press.

Zaim, M. (Eds). 2005. Applied Linguistics: Selected Reading for Classroom Discussion. Volumes 1 and 2. Padang: Postgraduate program, State University of Padang. 